
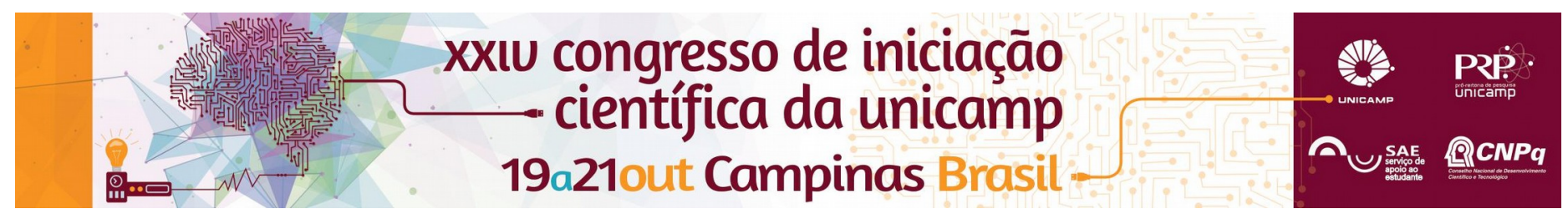

\title{
Corpo e Lugar: os sentidos do nu na arte de Regina José Galindo
}

\author{
Stephanie Ares Maldonado* (IC), Eduardo J. Marandola Jr. (Prof. Dr.)
}

\section{Resumo}

Como nos aprofundar no debate entre corpo e lugar pela perspectiva da Geografia Humanista? A experiência é um dos meios chaves para sairmos das representações de ambos os conceitos em direção às essências. $E$ a arte é uma potente expressão do corpo senciente-sensível no mundo, portanto, muito tem a nos mostrar sobre nós mesmos e sobre os lugares que habitamos e que se circunscrevem na nossa vida. Deste modo, trabalharemos sob um olhar embasado na fenomenologia do filósofo Maurice Merleau-Ponty e com a obra da artista performática guatemalense Regina José Galindo, artista da memória, do sofrimento, silêncio e feminino.

\section{Palavras-chave: \\ Circunstancialidade, Dimensão Sensível, Maurice Merleau-Ponty}

\section{Introdução}

O sentido que o artista põe em sua obra, nem sempre é o percebido pelo expetador, pois o sentido da experiência está na relação entre os dois. Temos que nos abrir à obra de arte tanto quanto a nós mesmos para que consigamos compreendê-la.

Compartilhamos um mundo com o artista e, por isso, nossa comunicação com a obra é possível. Mas, "segundo Balzac ou segundo Cézanne", o artista "assume a cultura desde seu começo e funda-a novamente" (MERLEAU-PONTY, 2004, p.139) ${ }^{1}$. Galindo realiza esse feito, através de uma obra política que critica as desigualdades sociais e de gênero, inicialmente na Guatemala, sua terra natal, e depois por outros lugares que se cirscuncreveram na sua trajetória.

Nas performances de Galindo, seu corpo nu muito nos diz. A nudez é colocada compondo a essência das obras, protagonizando-as. Olhamos para esse corpo nu, nesta obra nua, buscando descrever elementos que nos permitiam aprofundar no debate entre corpo e lugar, pela perspectiva da Geografia Humanista e pelo caminho percorrido na fenomenologia merleu-pontiana.

\section{Resultados e Discussão}

Cada lugar possui suas próprias identidades, experiências e memórias (DE PAULA, MARANDOLA JR., 2011) ${ }^{11}$, que agem sobre nós tanto quanto agimos sobre elas. A obra de Galindo trabalha diretamente com a memória coletiva da Guatemala, principalmente no que diz respeito à guerra civil (1960-1996) e ao sofrimento que, provindo dela, permanece ativo até hoje. Com elementos visuais criados sob um corpo de marcas e histórias, a artista desperta, no silêncio e na tensão criada, o sofrimento dos oprimidos, que ecoam em nossos corpos sencientes-sensíveis (CASALINI, 2013, p.30)"11. Isso é facilmente observável na obra "Tierra" (França/2013), onde ela mostra o modo como o exército matou durante o "genocídio" que foi a guerra (GALINDO, 2013) $)^{111}$

Ao se dispensar a indumentária e se colocar nas situações das obras, Galindo mostra e cria sentidos e símbolos, de um corpo guatemalense feminino que expõe fraquezas perante um mundo de desigualdades e de violência, mas forças que configuram resistência e resiliência. Na performance "Piedra" (Brasil/2007), uma nova moralidade é instalada, onde nenhum corpo nu, até mesmo sendo urinado, é capaz de chocar mais do que a violência. Como diria a artista "Soy una piedra; en mí; la história del mundo" (GALINDO, 2013), palavras que expressam o quanto as pessoas podem se tornar "pedras" para sobreviverem em sua vulnerabilidade (DE PAULA, MARANDOLA JR., 2011).

\section{Conclusão}

Perdemos nossa intimidade com a nudez, mesmo ela sendo natural. De todos os diversos sentimentos que ela pode despertar, Galindo espera que percebamos através dela o pedido de socorro que os corpos latinos-femininos exalam perante a violência e massacre cotidiano dos oprimidos.

\section{Agradecimentos}

À instituição de fomento (CNPq), aos membros do Laboratório de Geografia dos Riscos e Resiliência (LAGERR/UNICAMP) e aos amigos e família.

\footnotetext{
${ }^{1}$ MERLEAU-PONTY, Maurice. O olho e o espírito. Cosac Naify Portátil. São Paulo: Cosac Naify, 2013.

${ }^{11}$ DE PAULA, Luiz Tiago; MARANDOLA JR, Eduardo. Memória e experiência no estudo da vulnerabilidade. Dinâmicas demográficas e ambiente. Campinas: Nepo. Unicamp, v. 1, n. 1, p. 143156, 2011.

${ }^{111}$ CASALINI, Giulia. Feminist embodiments of silence. Performing the intolerable speech in te work of Regina José Galindo. Ex aequo, Vila Franca de Xira, n. 27, p. 27-41, 2013.

${ }^{1111}$ GALINDO, Regina José. Portfólio. Disponível em:

http://www.reginajosegalindo.com/. Acessado em: abril de 2016.
} 